\title{
Performance of Soft Asphalt and Double Otta Seal within First Three Years
}

\author{
Audrius Vaitkus, Viktoras Vorobjovas, Faustina Tuminienè, and Judita Gražulytė \\ Roads Research Institute, Vilnius Gediminas Technical University, Linkmenu g. 28, 80217 Vilnius, Lithuania \\ Correspondence should be addressed to Audrius Vaitkus; audrius.vaitkus@vgtu.lt
}

Received 16 June 2016; Accepted 25 July 2016

Academic Editor: Ana S. Guimarães

Copyright (C) 2016 Audrius Vaitkus et al. This is an open access article distributed under the Creative Commons Attribution License, which permits unrestricted use, distribution, and reproduction in any medium, provided the original work is properly cited.

Gravel roads play an important role in the transport infrastructure. However, their maintenance (especially the control of dustiness using chemical dust suppressants) is expensive. Besides, the condition of gravel roads results in low driving comfort, longer travelling time, faster vehicle amortization, and so forth. Typically, these problems are solved by paving gravel roads with asphalt wearing layer. However, north countries practice had shown pavement structure high susceptibility to frost due to insufficient thickness of frost resistance layer. The construction of thicker frost resistant layer increases road construction cost by $25 \%$ and, in most cases, there is no need to increase bearing capacity by increasing total thickness of pavement structure. In 201219 gravel roads were constructed using cost effective rehabilitation technologies-soft asphalt and double Otta Seal in Lithuania. This paper focuses on those two technologies' performance within first three years of constructed roads exploitation. The implemented experimental research consisted of three parts by evaluating constructed roads base layers bearing capacity; pavement roughness; and pavement distresses and defects. As a result, the acceptable performance indicators were determined for both technologies-soft asphalt and double Otta Seal. Also recommendations for construction and exploitation improvement were defined.

\section{Introduction}

Gravel roads play an important role in the transport infrastructure. They connect rural areas, recreation zones, and forestry into a single transport system. However, the maintenance of these kinds of roads requires a high part of the budget especially if the subgrade soils are weak. Praticò et al. [1] analysed life-cycle costs when subgrade is lime stabilized and lime-cement stabilized and nonstabilized. Lime-cement stabilized subgrade sections showed lower long-term costs than a nonstabilized or lime stabilized subgrade because treated sections perform better and lead to a reduction in the maintenance activities. Moreover, gravel roads result in a low driving comfort, longer time of travel, faster vehicle amortization, and dustiness.

Laurinavičius and Žilionienè [2] determined that the driving speed on gravel roads is about $0.55-0.80$ time lower than that on paved roads. It results in the loss of $0.25-$ 0.82 hours per 100 kilometers. Also, on gravel roads, the vehicle operating cost increases from 1.35 up to 1.90 times in comparison with paved roads.
The dustiness is caused by unbound aggregate particles, which are thrown up by passing vehicles. Jones [3] found out that vehicles travelling at speed of $75 \mathrm{~km} / \mathrm{h}$ (on gravel roads with annual average daily traffic (AADT) equal to 100 vehicles per day (vpd)) threw up about 25 tons of gravel wearing layer aggregate annually per kilometer. It results in the reduction of thickness-approximately $4 \mathrm{~mm}$ of 7 meters in roads' width [4]. Due to the deficiency in the thickness of wearing layer, the roads gradually become instable and corrugated. This causes more frequent maintenance activities leading to higher overheads. Furthermore, the dustiness obscures the visibility for drivers and therefore it causes the traffic accidents [5]. Dust is also a health hazard because it causes allergies and asthma and accumulates in the human respiratory tract $[6,7]$. Also, it contains ingredients that are toxic to vegetation or water life [8].

Consequently, the control of dustiness is one of the most important activities of the maintenance. Typically, dustiness is restricted applying chemical dust suppressants, for example, calcium or magnesium chloride and calcium lignosulphonate. The analysis of the literature revealed that 
chemical dust suppressants might reduce the dustiness up to $80 \%$ and the total aggregate loss up to $42-61 \%[9,10]$. The efficiency is maximized when surface moisture is 3-4\% [11]. However, in rainy regions, chemical dust suppressants are an uneconomical method to control the dustiness because they leach from the gravel [12].

The permanent solution for control of dustiness is the paving of gravel roads. However, naturally, it is impossible due to the lack of funds. For instance, according to Lithuanian Roads Administration under the Ministry of Transport and Communication data (2015), in Lithuania, more than third (33.9\%) of state roads are gravel roads. The paving of all these roads needs millions of Euros. Also, the volume of traffic in many gravel roads is so low that paving is not economically feasible. According to Lithuanian requirements, gravel roads are paved if $\mathrm{AADT} \geq 150 \mathrm{vpd}$ in nonresidential area and if $\mathrm{AADT} \geq 80 \mathrm{vpd}$ in residential area.

As a rule, in Lithuania, gravel roads are paved with a single-layer asphalt pavement. The thickness depends on the number of equivalent single axle loads (ESALs) and usually varies from $6 \mathrm{~cm}$ to $10 \mathrm{~cm}$. However, practice has shown that this kind of pavement is susceptible to frost because there is too thin frost resistance layer. It is solved by laying more than $30 \mathrm{~cm}$ thick layer of less frost-susceptible soils or improving subgrade. Unfortunately, those additional works increase roads construction cost up to $25 \%$ and usually are not fulfilled [13]. Also, during the construction of new asphalt pavement, the plan and longitudinal profile of road are not corrected [14]. This results in less traffic safety. Therefore, the construction of asphalt concrete pavement is also unpractical and uneconomical rehabilitation technology for gravel roads.

In foreign countries, gravel roads are effectively rehabilitated using soft asphalt or Otta Seal technologies [15-20]. These kinds of technologies do not increase bearing capacity but prevent pavement from moisture infiltration and loss of aggregates and improve driving conditions. Hence, the construction of soft asphalt or Otta Seal reduces the maintenance cost and results in a social satisfaction.

\section{Concept of Soft Asphalt and Otta Seal Technologies}

Soft asphalt consists of aggregates, aggregates filler, and soft (low viscosity) bituminous binder. The requirements for soft asphalt are specified in Standard EN 13108-3. There are several types of soft asphalt (type A; type B; type C; and type S). The type is chosen according to desirable mechanical properties of asphalt mixture under specific climatic conditions.

The practice has shown that soft asphalt requires low temperature mixing and is elastic, durable, self-healing, well workable, recyclable, and so forth. However, it has low light reflection and limited resistance to abrasion. Sometimes it is unstable or it can form a water film on a new constructed pavement. Also, the flux used for binder is environmentally unfriendly [15-17]. Nevertheless, the soft asphalt is a practical rehabilitation technology for gravel roads due to its property - self-healing. Under high temperature bitumen becomes significantly softer and cracks heal in soft asphalt wearing layer. It results in less pavement susceptibility to frost heaves and fatigue damage.

Based on the Swedish General Technical Construction Specifications for Roads [16], a single wearing layer of soft asphalt is laid on gravel roads with AADT $\leq 500 \mathrm{vpd}$. Other layers of the pavement structure shall meet the requirements of the thickness.

Otta Seal consists of soft (low viscosity) binder spraying on the surface followed by the spreading and rolling graded aggregates. The layer thickness is about $16-32 \mathrm{~mm}$ depending on the number of layers (single or double). Rolling and trafficking push aggregate particles into binder layer and the binder rises upwards through the aggregate particles and mechanically interlocks them. It results in a dense, durable matrix [21].

The practice has shown that Otta Seal is a durable and flexible pavement surface. It is tolerant of relatively high deflections, which are expected on low-volume roads. Also, the dense and closed texture slows down the rate of oxidation of the surfacing; that is, it slows binder ageing and hardening. Furthermore, there is a scope for utilizing labour-based methods in many aspects of Otta Seal construction. The main advantage is the ability to use relatively inferior aggregates, for example, screened gravel instead of crushed rock. It results in low construction cost $[20,21]$.

The main disadvantage of the Otta Seal is its initial, inconsistent, and somewhat patchy appearance during the first 4-6 months of service life and a need for postconstruction care (especially, 3-4 weeks after construction). During this stage, the surface may become rich in bitumen or even "bleed." On this kind of areas, sand or crushed dust is spread. It absorbs the excess of bitumen. Also, a newly constructed Otta Seal can be dusty and produce "flying stones" [20, 21]. The performance of Otta Seal strongly depends on adequate design and quality of construction [19]. When double Otta Seal is constructed, a minimum period of $8-12$ weeks is needed between the construction of the first and the second layers [20].

The application of Otta Seal is based on the traffic level. It is recommended to use the single Otta Seal with sand cover seal when the AADT $\leq 500 \mathrm{vpd}$ and the double Otta Seal when the AADT > 500 vpd [20-22]. These recommendations are flexible and depend on projects.

\section{Experimental Roads Sections of Soft Asphalt and Double Otta Seal}

In Lithuania 19 roads sections of gravel were constructed using cost effective rehabilitation technologies. In 5 roads sections (total length $7.39 \mathrm{~km}$ ) the wearing layer was soft asphalt; in 14 roads sections (total length $12.57 \mathrm{~km}$ ) it was double Otta Seal (Table 1). In all roads sections AADT was less than 500 vpd except road number 4028 where AADT was $640 \mathrm{vpd}$ (Figure 1). The number of equivalent single axle loads (ESALs) was less than $0.1 \mathrm{mln}$ in all roads sections. All roads sections were grouped into five segments according to Lithuanian regions, that is, KlaipedaTauragè, Šiauliai-Telšiai, Panevěžys-Utena, Vilnius-Alytus, 
TABLE 1: Experimental roads sections of soft asphalt and double Otta Seal.

\begin{tabular}{|c|c|c|c|c|}
\hline Road number & Road name & Road section $(\mathrm{km})$ & Length $(\mathrm{km})$ & $\begin{array}{c}\text { Type of wearing } \\
\text { layer }\end{array}$ \\
\hline \multicolumn{5}{|c|}{ Klaipèda-Tauragè } \\
\hline 1708 & Padubysys-Vosbutai-Butkiškè-Putriai & $9.70-10.35$ & 0.65 & Double Otta Seal \\
\hline 1716 & Pilis-Raudonènai & $3.80-5.20$ & 1.40 & Soft asphalt \\
\hline 1717 & Armeniškiai-Aukštvilkiai & $9.19-9.30$ & 0.11 & Double Otta Seal \\
\hline $4516(1)$ & Skaudvilè-Bijotai-Kelias Kaltinènai-Kražiai & $9.95-10.90$ & 0.95 & Double Otta Seal \\
\hline $4516(2)$ & Skaudvilè-Bijotai-kelias Kaltinènai-Kražiai & $10.90-11.53$ & 0.63 & Double Otta Seal \\
\hline \multicolumn{5}{|l|}{ Šiauliai-Telšiai } \\
\hline 2735 & Tirkšliai-Lèteniai & $2.00-2.62$ & 0.62 & Double Otta Seal \\
\hline 3208 & Rietavas-Lioliai-Mažieji Mostaičiai & $17.75-19.48$ & 1.73 & Double Otta Seal \\
\hline 4028 & Kairiai-Vègeliai & $1.11-2.12$ & 1.01 & Soft asphalt \\
\hline 4118 & $\begin{array}{l}\text { Laukuva-Vaitkaičiai-Kelias } \\
\text { Rietavas-Tverai-Varniai }\end{array}$ & $9.30-10.00$ & 0.70 & Double Otta Seal \\
\hline \multicolumn{5}{|c|}{ Panevėžys-Utena } \\
\hline 1235 & Kurtiniai-Aušra & $0.80-2.12$ & 1.32 & Double Otta Seal \\
\hline 2427 & Salamiestis-Stuburiai & $1.70-3.10$ & 1.40 & Double Otta Seal \\
\hline 2430 & Subačius-Čečeliai & $0.65-1.75$ & 1.10 & Soft asphalt \\
\hline \multicolumn{5}{|l|}{ Vilnius-Alytus } \\
\hline 2518 & Veisiejai-Vainiūnai-Barzdžiūnai & $0.75-3.30$ & 2.55 & Soft asphalt \\
\hline 3918 & Jašiūnai-Keidžiai & $3.43-4.03$ & 0.60 & Double Otta Seal \\
\hline 4726 & Grendavè-Gruožninkai & $0.00-1.05$ & 1.05 & Double Otta Seal \\
\hline 5017 & Noškūnai-Panočiai & $7.52-8.38$ & 0.86 & Double Otta Seal \\
\hline 5235 & Šumskas-Vindžiūnai-Medininkai & $4.23-5.56$ & 1.33 & Soft asphalt \\
\hline \multicolumn{5}{|c|}{ Kaunas-Marijampolè } \\
\hline 2642 & Mikoliškiai-Jakimavičiai & $0.00-0.95$ & 0.95 & Double Otta Seal \\
\hline 5123 & Gižai-Balsupiai & $2.50-3.50$ & 1.00 & Double Otta Seal \\
\hline
\end{tabular}

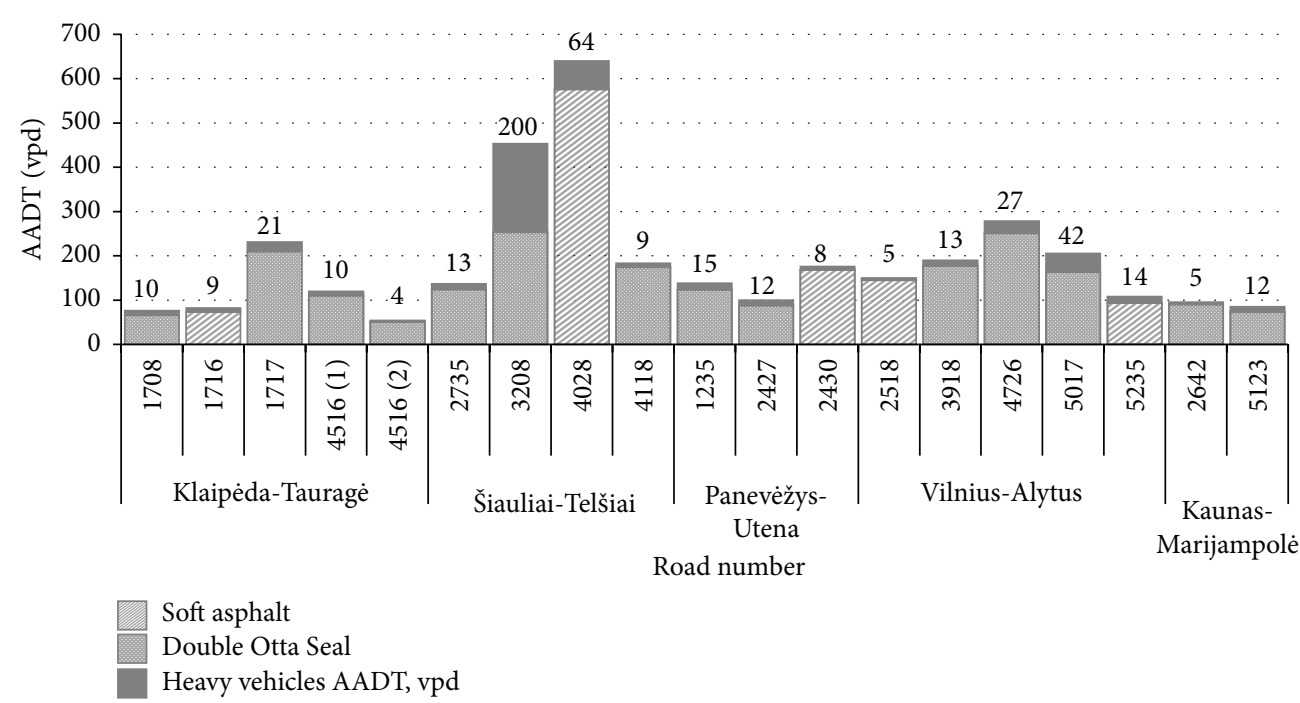

FIGURE 1: AADT and heavy vehicles AADT at experimental roads sections.

and Kaunas-Klaipèda. Each region presents specific climatic conditions. All roads sections were constructed in 2012.

Soft asphalt was laid on the newly constructed unbound base layer of crushed stones that was on the existing gravel pavement. The thickness of the wearing layer and base layer was $4.5 \mathrm{~cm}$ and $15 \mathrm{~cm}$, respectively. If the thickness of the existing gravel pavement was lower than $35 \mathrm{~cm}$, it was increased using unbound materials.
The type of soft asphalt was selected according to the laboratory tests results assessed by the SAW method [13, 23]. Lithuanian experience in gravel roads rehabilitation using single-layer asphalt pavement revealed most suitable aggregate fraction $(0 / 16)$ for typical asphalt concrete [24]. As a result, the soft asphalt SA 16-d-V6000 type $C$ was used. In this case, there were required minimum binder content of $4.5 \%$, air voids content of $4.0-9.0 \%$, and indirect tensile ratio 
TABLE 2: Characteristics of soft asphalt (SA 16-d-V6000 type C).

\begin{tabular}{|c|c|c|c|c|c|}
\hline \multirow{2}{*}{ Characteristic } & \multicolumn{5}{|c|}{ Road number } \\
\hline & 1716 & 2430 & 2518 & 4028 & 5235 \\
\hline Binder V6000 content (\%) & 4.7 & 5.0 & 4.7 & 4.8 & 4.6 \\
\hline Air voids content $(\%)$ & 5.5 & 6.5 & 5.5 & 6.9 & 6.3 \\
\hline Ratio of indirect tensile strengths (ITS) & 60.0 & 99.8 & 66.0 & 68.0 & 71.0 \\
\hline
\end{tabular}

TABLE 3: Characteristics of bitumen emulsions.

\begin{tabular}{lccc}
\hline Bitumen emulsion type & Characteristics & $\begin{array}{c}\text { Chen } \\
\text { Kinematic viscosity }\left(\mathrm{mm}^{2} / \mathrm{s}\right)\end{array}$ & Adhesion $(\%)$ \\
\hline C60B1PA-V6000 & $60.3-62.3$ & $5305-10384$ & $80-100$ \\
C60BF1-PA & $57.0-61.5$ & $4481-8713$ & $30-80$ \\
\hline
\end{tabular}

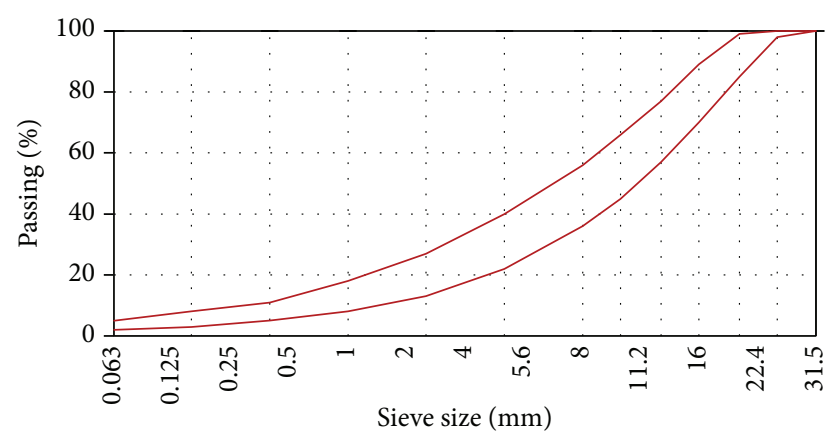

Figure 2: Aggregate gradation for double Otta Seal.

not less than 60. The characteristics of soft asphalt (SA 16-dV6000 type C) in analysed sections are represented in Table 2.

Double Otta Seal was laid on the newly constructed unbound base layer of crushed stones that was on the existing gravel pavement. The thickness of the base layer was between $7 \mathrm{~cm}$ and $10 \mathrm{~cm}$. If the thickness of the existing gravel pavement was lower than $30 \mathrm{~cm}$, it was increased using unbound materials.

Double Otta Seal was used that consisted of 0/16-fraction aggregate and bitumen emulsion. The aggregate gradation of $0 / 16$ fractions is shown in Figure 2. The passing through the $0.063 \mathrm{~mm}$ sieve size had to be between $2 \%$ and $5 \%$. The resistance to fragmentation according to the impact resistance value was $\mathrm{SZ}_{18} \leq 18 \%$ and Los Angeles coefficient was $\mathrm{LA}_{20} \leq 20 \%$. Two bitumen emulsions were used: C60B1PA-V6000 and C60BF1-PA. Their characteristics are represented in Table 3 . The aggregate was spread $14 \mathrm{~L} / \mathrm{m}^{2}$. However, it could be corrected according to the aggregate spread test results. Adhesive additives were not used.

The bearing capacity of the base layer had to be not less than $120 \mathrm{MPa}$ in both rehabilitation cases.

\section{Research on Soft Asphalt and Double Otta Seal Performance}

The research on soft asphalt and double Otta Seal performance consisted of three parts:

(i) evaluation of bearing capacity of the base layer; (ii) evaluation of the pavement roughness;

(iii) qualitative visual assessment of defects.

Bearing capacity of the base layer was evaluated after its construction by static plate load test according to Lithuanian Standard LST 1360.10.

Pavement roughness was evaluated at the beginning of the service (autumn 2012) and after 1 year of the operation (summer 2013) by International Roughness Index (IRI). The Roads Surface Profilometer Dynatest 5051 RSP and the Mobile Roads Survey Laboratory RST 28 were used.

The qualitative visual assessment of defects was carried out annually. Roads sections of soft asphalt were assessed in spring and summer; roads sections of double Otta Seal were assessed in spring and autumn. Longitudinal cracking, transverse cracking, potholes, raveling, seals, and bleeding were the main factors representing soft asphalt performance. The performance of double Otta Seal was evaluated by three groups of defects and longitudinal and transverse cracks. The first group $\left(\mathrm{P}_{1}\right)$ comprised fatting-up, bleeding, and tracking. The second group $\left(\mathrm{P}_{2}\right)$ consisted of scabbing, tearing, and longitudinal joint crack. The third group $\left(\mathrm{P}_{3}\right)$ was streaking. All defects which are the criteria for assessing the pavement performance are shown in Figure 3.

The amount of defects (except streaking) was expressed in percentage. It characterized the area or length (if there were analysed longitudinal and transverse cracks) of distressed pavement. The streaking was expressed in meters. It presented the length of the line or lines in which were lost chippings from a completed surface dressing.

The results of the qualitative visual assessment of defects strongly depend on researcher's experience. Besides, the complexity of the assessment of fatting-up, bleeding, and tracking was noticed after first inspection of double Otta Seal performance. That is why in the report it was suggested to write $5 \%, 10 \%, 30 \%, 50 \%$, and more than $50 \%$ if pavement suffers from fatting-up, bleeding, and tracking, from $0 \%$ to $5 \%$, from $5 \%$ to $10 \%$, from $10 \%$ to $30 \%$, from $30 \%$ to $50 \%$, and more than $50 \%$, respectively.

\section{Results and Discussion}

5.1. Influence of the Base Layer Bearing Capacity on Soft Asphalt and Double Otta Seal Performance. The bearing 


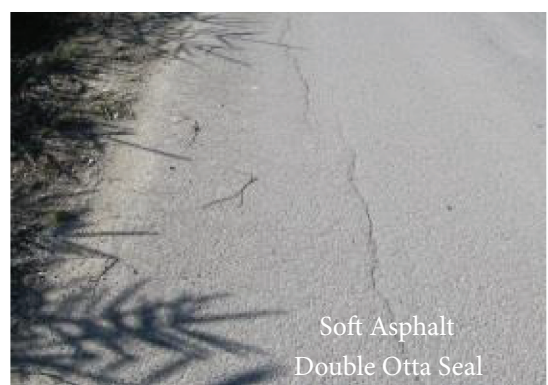

Longitudinal crack

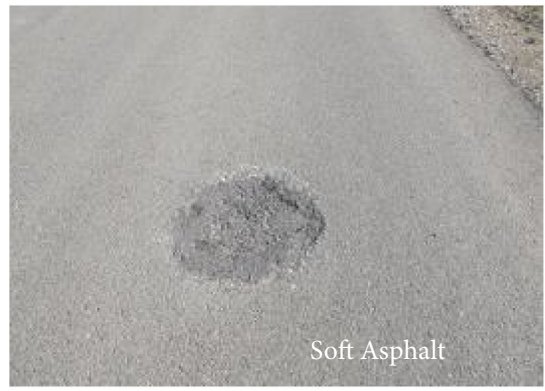

Pothole

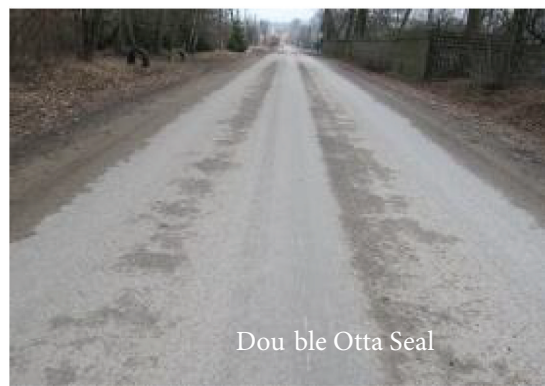

Streaking

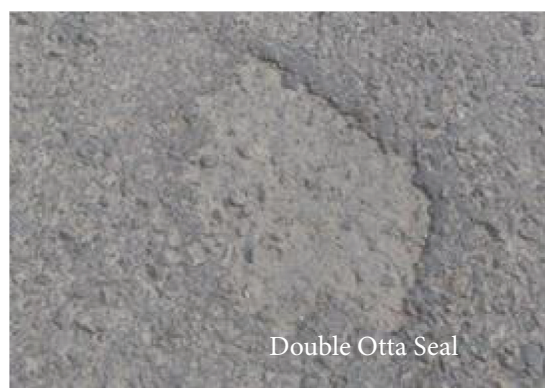

Scabbing

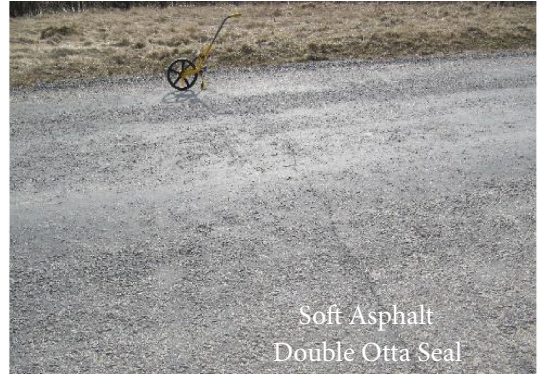

Transverse crack

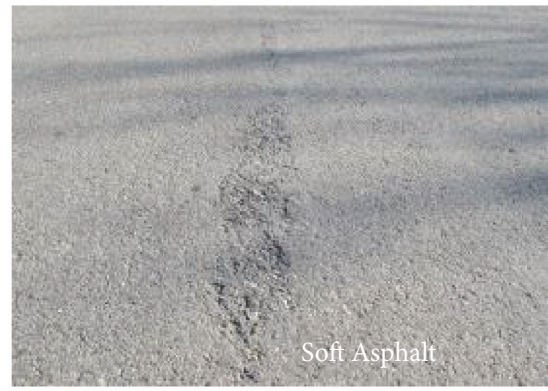

Ravelling

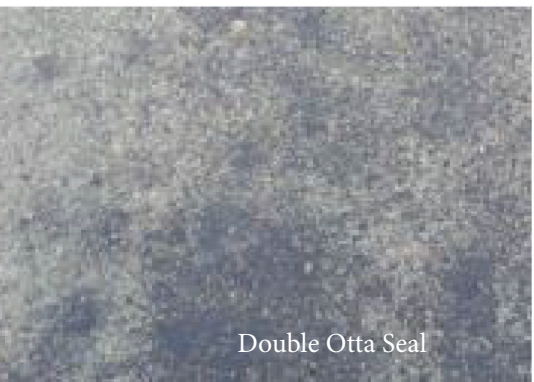

Fatting up and bleeding

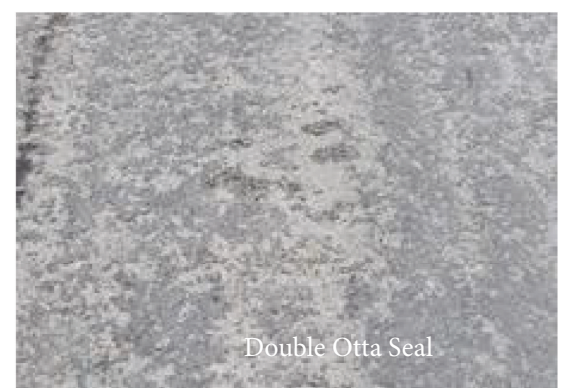

Tearing

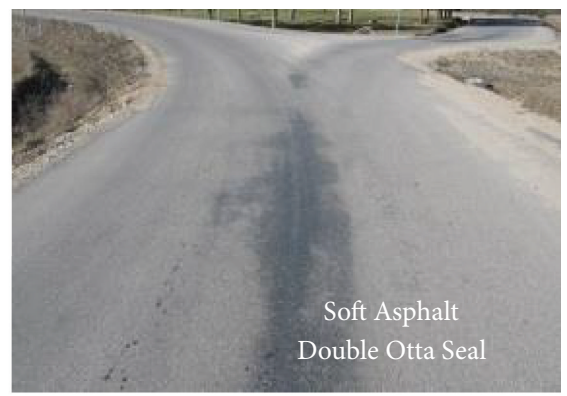

Bleeding

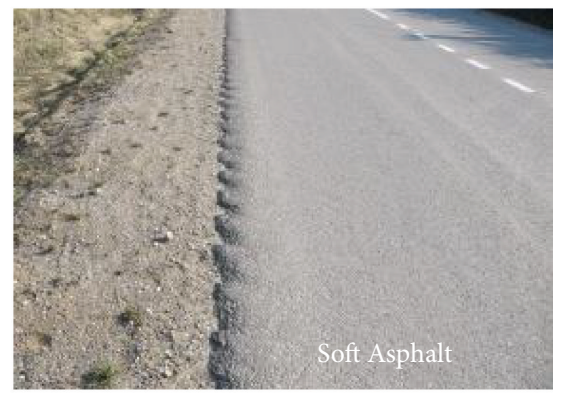

Seals

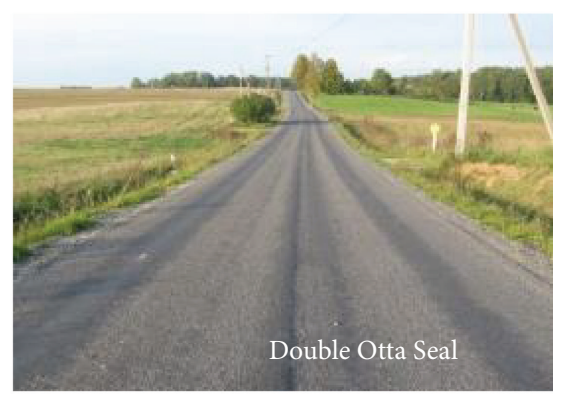

Tracking

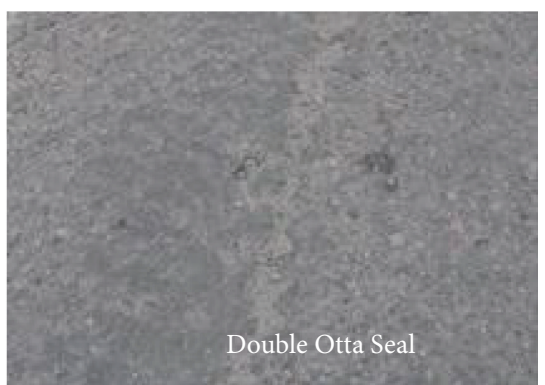

Longitudinal joint crack

FIGURE 3: Defects that are the criteria for assessing the pavement performance.

capacity of the base layer after its construction is presented in Figure 4. In all roads sections the average deformation module $E_{v 2}$ reached the requirement of $120 \mathrm{MPa}$. The highest value $(255.63 \mathrm{MPa})$ was on road number $4516(1)$; the lowest $(132.58 \mathrm{MPa})$ was on road number 2735 . However, in three roads sections, that were covered with double Otta Seal (road number 1716, road number 3208, and road number 2642), some individual values were less than $120 \mathrm{MPa}$. The lowest value was $77.94 \mathrm{MPa}$ on road number 1716 . Nevertheless, the base layer bearing capacity is sufficient and has not a negative impact on the wearing layer performance. However, the required deformation module $E_{v 2}$ of $120 \mathrm{MPa}$ has to be ensured within the whole year, especially during the spring thaw when the unbound base layers and subgrade are the weakest. Thus, there is a need to verify the bearing capacity of the base layer as the frost disappears from the pavement 


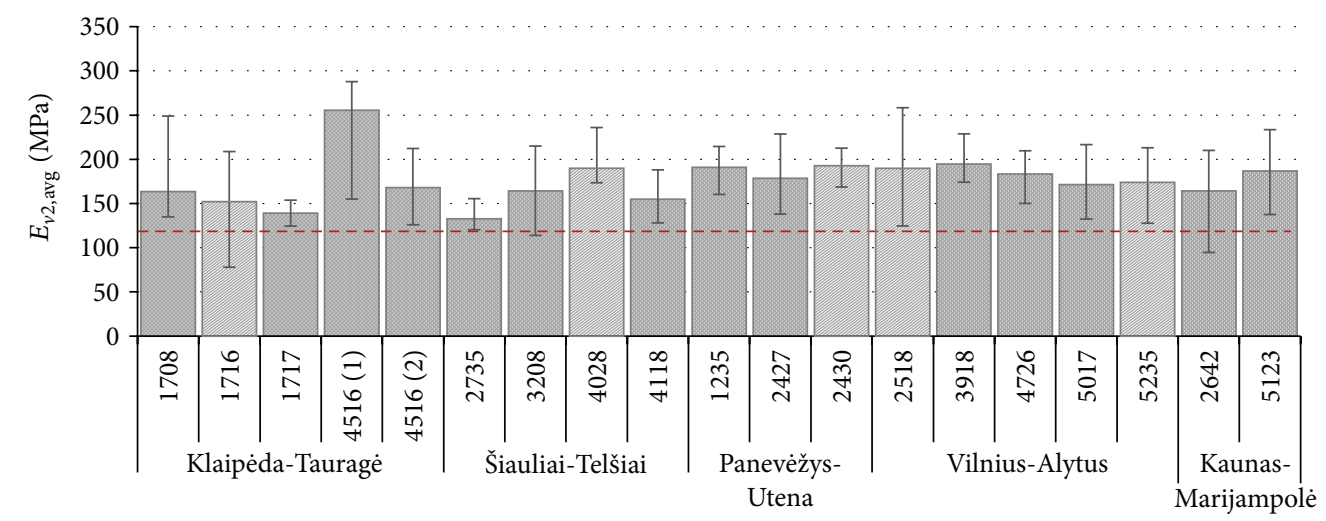

Soft asphalt

Double Otta Seal

$\top E_{v 2, \max }$

Road number

$\perp E_{v 2 \text {,min }}$

FIGURE 4: Bearing capacity of the base layer (horizontal hyphenated line shows the required minimum value).

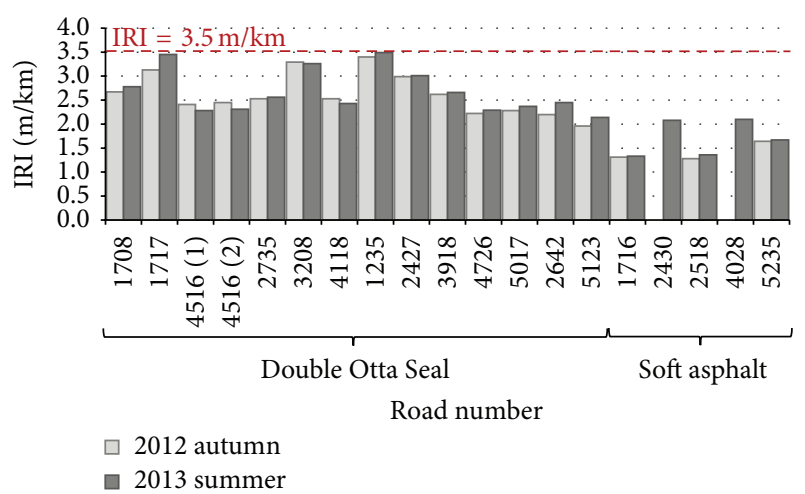

FIGURE 5: IRI (horizontal hyphenated line shows the maximum value).

structure. The back calculation of $E$ module from the Falling Weight Deflectometer (FWD) data is a reasonable method for base layer bearing capacity evaluation.

5.2. Evaluation of the Pavement Roughness. The pavement roughness at the beginning of the service (autumn 2012) and after 1 year of the operation (summer 2013) expressed by IRI is shown in Figure 5. In both cases in all roads sections IRI met the requirement of $3.5 \mathrm{~m} / \mathrm{km}$ that is specified for roads of regional significance in Lithuania. At the beginning of the service, the average IRI of roads sections covered with double Otta Seal and soft asphalt was $2.62 \mathrm{~m} / \mathrm{km}$ and $1.41 \mathrm{~m} / \mathrm{km}$, respectively. The roughness of road sections covered with soft asphalt reached the requirement for main roads (IRI $\leq$ $1.5 \mathrm{~m} / \mathrm{km}$ ). Double Otta Seal showed higher roughness than soft asphalt because of its nature and texture. The surface smoothness of double Otta Seal improves within trafficking; that is, vehicles push down the aggregate particles, and after 8-12 weeks it results in a more uniform and consistent appearance, which looks somewhat like the asphalt concrete. After 1-year operation the average IRI of roads sections covered with double Otta Seal and soft asphalt increased by
$2.18 \%$ and $21.13 \%$, respectively. The consequence is pavement deterioration, especially the formation and development of longitudinal cracks, ravelling, and seals on road sections covered with soft asphalt. Nevertheless, the average IRI of these roads sections reached only $1.71 \mathrm{~m} / \mathrm{km}$ and was less than that of roads sections covered with double Otta Seal. On each road section covered with double Otta Seal (except road number 4516 (1), road number 4516 (2), road number 3208, and road number 4118) and soft asphalt the roughness averagely increased about $4.80 \%$ and $3.20 \%$, respectively. On road number 4516 (1), road number 4516 (2), road number 3208, and road number 4118 the roughness averagely decreased about $3.99 \%$. This could have occurred because of imprinted aggregate particles in spread bitumen emulsion layer. On each analysed road section since 2013 no roughness measurements have been carried out. Thus, after 4 years of operation, the implementation of roughness measurements would be a reasonable data evaluating the pavement performance. However, these measurements should be performed only on roads sections covered with soft asphalt because the surface of double Otta Seal is not adequate for asphalt mixture.

5.3. Qualitative Visual Assessment of Defects. On roads sections with soft asphalt within three years of exploitation, longitudinal cracks, transverse cracks, bleeding, potholes, ravelling, and seals have been observed. The degree of pavement suffering from longitudinal cracks on each road section is shown in Figure 6. Longitudinal cracks are expressed in percentages as the ratio of cracks length to road section length. The most distressed road section is road number 2430. It is located in Panevėžys-Utena region. It was evaluated that the average amount of longitudinal cracks within three years of operation is $15.71 \%$. The maximum value of $20.05 \%$ and the lowest value of $6.93 \%$ on road number 2430 were determined in spring 2014 and summer 2013, respectively. In summer 2013 the longitudinal cracks decreased by $62.98 \%$. This reduction is consequence of soft asphalt ability to self-heal under high pavement temperatures. However, in summer 2014, longitudinal cracks self-healed lower than previous year (only 


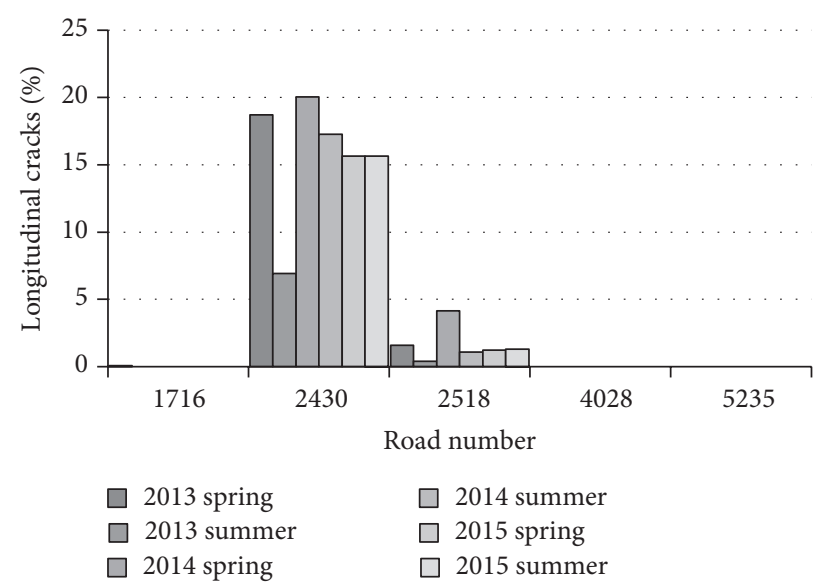

FIGURE 6: Longitudinal cracks on roads sections covered with soft asphalt.

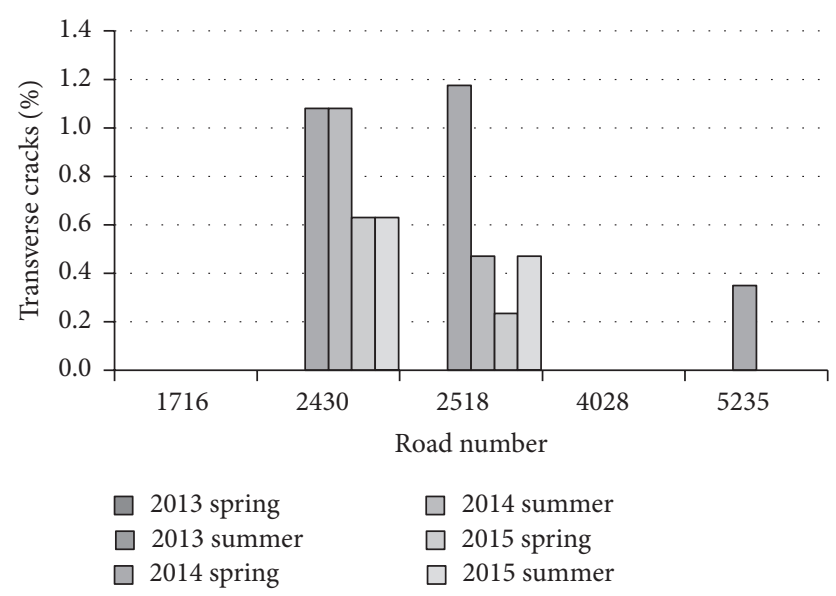

Figure 7: Transverse cracks on roads sections covered with soft asphalt.

13.90\%) and in summer 2015 they did not even change. This phenomenon was a result of less warm summer than in 2013.

In spring 2015 less transverse cracks were observed than in 2014 summer. These data might be determined because cracks healing could continue after conducted qualitative visual assessment of defects (typically the qualitative visual assessment of defects is carried out during the hottest period of summer) and the winter 2014/2015 was not severe. Similar tendencies of longitudinal cracks development were observed on road number 2518, which is located in Vilnius-Alytus region. There, the maximum and the minimum values were $4.15 \%$ and $0.39 \%$, respectively. On road number 1716 , which is located in Klaipeda-Taurage region, longitudinal cracks $(0.07 \%)$ completely healed in summer 2013 and have not formed again. In both roads (road number 4028, which is located in Šiauliai-Telšiai region, and road number 5235, which is located Vilnius-Alytus region) longitudinal cracks did not form from the beginning of exploitation.

The degree of pavement suffering from transverse cracks on each road section is shown in Figure 7. Transverse cracks are expressed in percentages as well as longitudinal

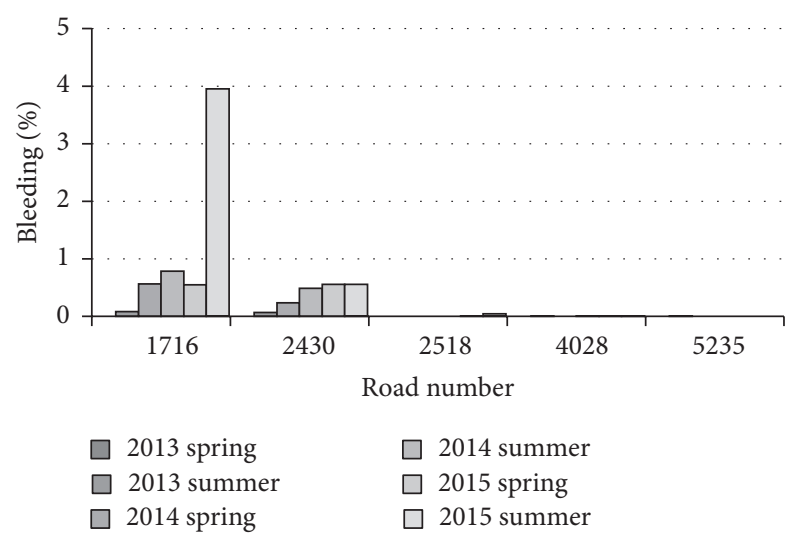

FIGURE 8: Bleeding on roads sections covered with soft asphalt.

cracks. Transverse cracks appeared after one year of operation (after 2013/2014 winter). The maximum value of $1.17 \%$ was determined on road number 2518 in spring 2014. However, it decreased by $60.00 \%$ in summer 2014 because of soft asphalt ability to self-heal under high pavement temperatures. The increase of transverse cracks on road number 2518 in summer 2015 and the tendency of longitudinal cracks development on road number 2430 are questionable because usually transverse cracks occur after winter and decrease only if wearing layer has self-healing property. On road number 5235 transverse cracks $(0.35 \%)$ completely healed in summer 2014 and have not formed again. In both roads (road number 1716 and road number 4028) transverse cracks have not formed from the beginning of exploitation.

The degree of pavement suffering from bleeding on each road section is shown in Figure 8. Bleeding is expressed in percentages as the ratio of area, in which bleeding has appeared, to road section area. Bleeding occurred after one year of operation (in summer 2014). The most distressed road section is road number 1716. It is located in KlaipedaTauragè region. On road number 1716 the average amount of bleeding within three years of operation is $1.18 \%$. There the maximum value of $3.95 \%$ and the lowest value of $0.08 \%$ were determined in summer 2015 and summer 2013, respectively. It was observed that on road number 2430 the bleeding is less than $0.38 \%$. On roads number 2518 , number 4028 , and number 5235, bleeding did not form. It only appeared in specific areas such as turning or breaking points and was less than $0.01 \%$. Road number 2518 and road number 4028 are located where the absolute maximum air temperature is even higher than $35^{\circ} \mathrm{C}$ during summer time. It reveals that bleeding does not depend on the maximum air temperature. However, the length of hot period might be a decisive factor in bleeding development. In analysed roads sections the binder content also does not influence bleeding because road number 1716 and road number 4028 were designed with the same binder content $(4.7 \%)$ and the performance considering bleeding is absolutely different.

Potholes appeared only on road number 2518 after half a year of operation. It was less than $0.01 \%$. Because of pavement deterioration it has increased 2.25 times but still remained less than $0.01 \%$. 


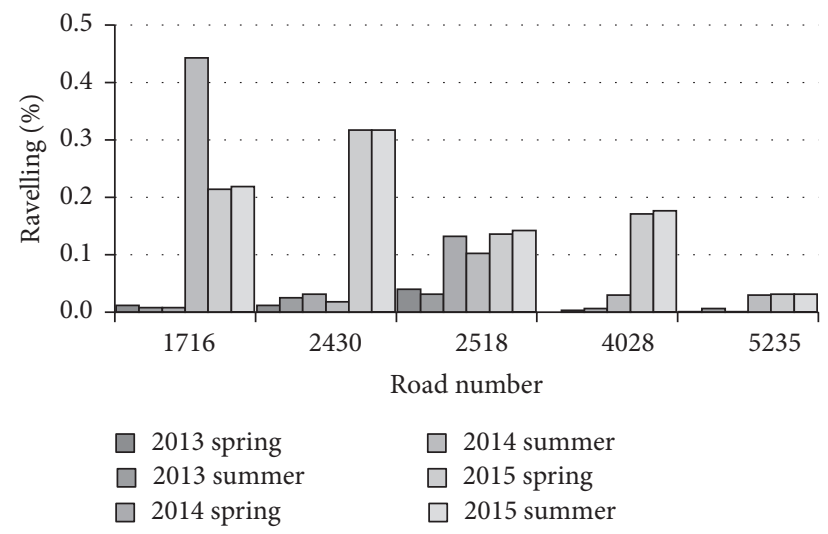

FIGURE 9: Ravelling on roads sections covered with soft asphalt.

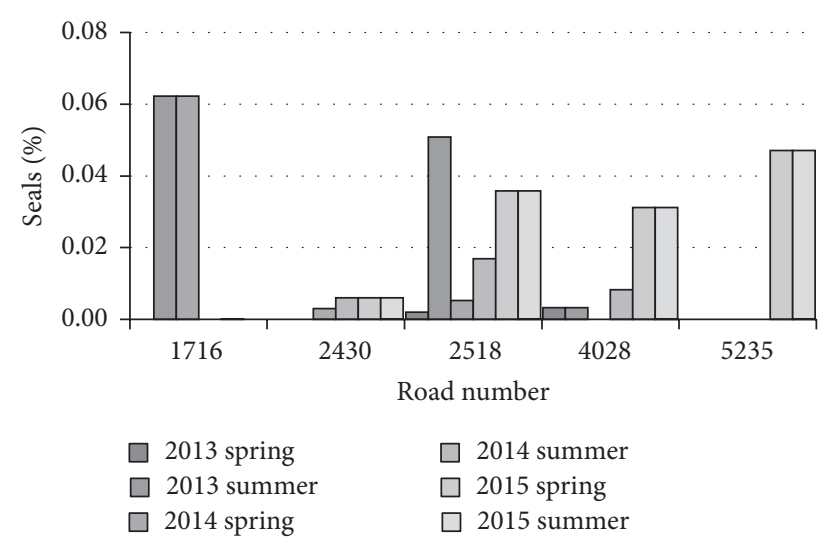

FIGURE 10: Seals on roads sections covered with soft asphalt.

The degree of pavement suffering from ravelling on each road section is shown in Figure 9. Ravelling is expressed in percentages as the ratio of area, in which ravelling has appeared, to road section area. In all analysed roads sections ravelling was lower than $0.5 \%$. The most distressed road section is road number 1716 . There the average amount of ravelling within three years of operation is $0.15 \%$. On the road number 1716 the maximum value of $0.44 \%$ and the lowest value of $0.01 \%$ were determined in summer 2014 and summer 2013, respectively. At least distressed road section is road number 5235.

There, the average amount of ravelling within three years of operation is only $0.02 \%$ and the maximum value of $0.03 \%$ was determined in spring 2015. The reason of ravelling is a reduction in adhesion, that is, the loss of bond between aggregate particles and the binder. It results from water on the pavement, which causes the loss of the binder, and vehicular traffic, which gradually ravels away the aggregate particles.

The degree of pavement suffering from seals on each road section is shown in Figure 10. Seals are expressed in percentages as the ratio of area, in which seals have appeared, to road section area. In all analysed roads sections the amount of seals was lower than $0.07 \%$. The most distressed road section is road number 2518. There the average amount of seals within three years of operation is $0.02 \%$. On road number 2518 the maximum value of $0.05 \%$ was determined in summer 2013. At least distressed road section is road number 2430. There the average amount of seals within three years of operation is almost zero. The consequence of seals is the traffic of large farm equipment, which usually broke the edge of the pavement. The decrease of seals (e.g., on road number 1716 and road number 2518) might happen because of routine maintenance.

On roads sections with double Otta Seal within three years of operation, longitudinal cracks, transverse cracks, fatting-up, bleeding, tracking, scabbing, tearing, longitudinal joint crack, and streaking have been observed. The degree of pavement suffering from longitudinal cracks on each road section is shown in Figure 11. These distresses have been observed since spring in 2014. Longitudinal cracks are expressed in the same manner as on the roads covered with soft asphalt. The most distressed roads sections are road number 1708, road number 4516 (1), and road number 2642. There the average amount of longitudinal cracks within three years of operation is $21.81 \%, 13.84 \%$, and $30.71 \%$, respectively. The maximum value of $48.42 \%$ was determined in autumn 2015 on road number 2642. Such a huge development of longitudinal cracks could happen because of too less bearing capacity during the spring thaw; then the unbound base layers and subgrade are the weakest. It also explains why on some roads (e.g., on road number 2642) the amount of longitudinal cracks in autumn was higher than in spring. On four roads (road number 4516 (2), road number 2735, road number 3918, and road number 5123) the average amount of longitudinal cracks within three years of operation varies from $1 \%$ to $9 \%$. Other roads are not prone to longitudinal cracks development because cracks appeared in less than $1 \%$ of road length. On some roads (e.g., on road number 1708, road number 4516 (1), and road number 4516 (2)) in autumn 2014 less longitudinal cracks were determined than in spring 2014. The reason is emulsion production used soft bitumen, which results in pavement self-healing under high pavement temperatures. However, this phenomenon was observed only in 2014.

The degree of pavement suffering from transverse cracks on each road section is shown in Figure 12. These distresses have been observed since spring in 2014. Transverse cracks are expressed in the same manner as on the roads covered with soft asphalt. The most distressed roads sections are road number 1235 and road number 5017. There the average amount of longitudinal cracks within three years of operation is $1.4 \%$ and $1.05 \%$, respectively. The maximum value of $4.19 \%$ was determined in spring 2014 on road number 5017. However, later, all transverse cracks disappeared. Besides, on road number 1235 in autumn 2014, transverse cracks decreased to $85.91 \%$.

Similar tendency of transverse cracks decrease was also observed on other roads. Hence, on the roads covered with double Otta Seal, transverse cracks self-heal under high pavement temperatures. Five roads (road number 1708, road number 1717 , road number 3918, road number 2642, and road number 5123) are resistant to development of transverse cracks. On other roads the average amount of transverse cracks within three years of operation was less than $1 \%$. 


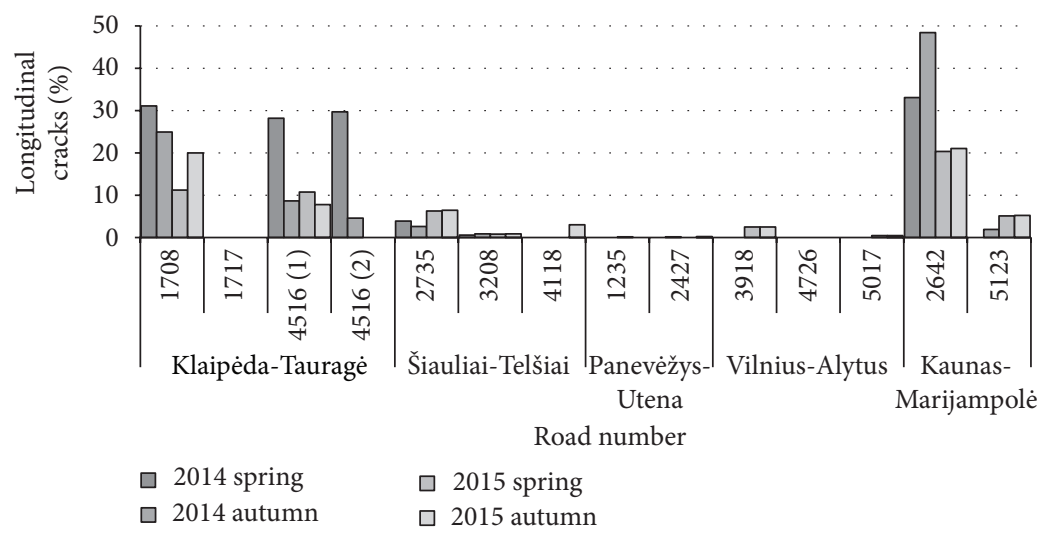

FIGURE 11: Longitudinal cracks on roads sections covered with double Otta Seal.

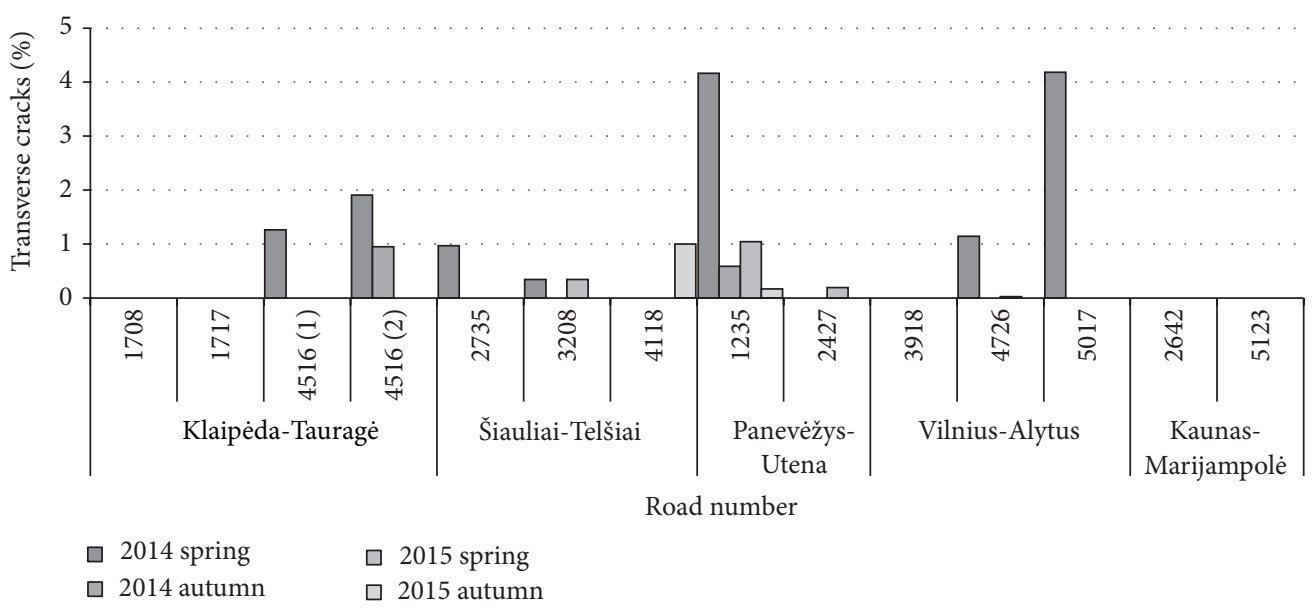

FIGURE 12: Transverse cracks on roads sections covered with double Otta Seal.

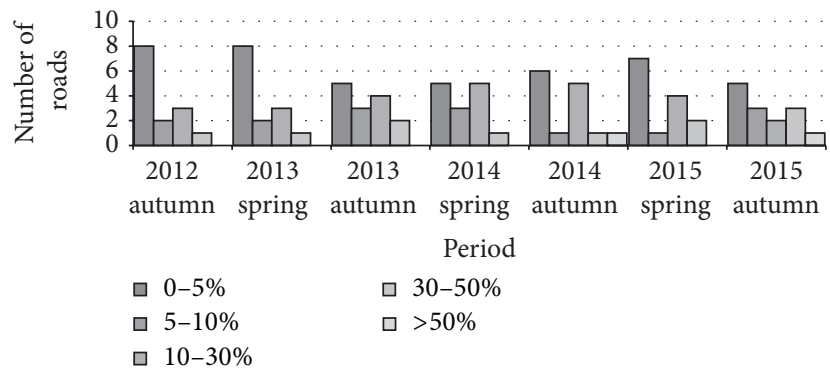

FIGURE 13: The number of roads sections covered with double Otta Seal according to severity of failure $\mathrm{P}_{1}$.

The degree of pavement suffering from $\mathrm{P}_{1}$ (fatting-up, bleeding, and tracking) on each road section is shown in Table 4 . These distresses have been dominated since roads construction and they have quite rapid development over time. In order to better evaluate double Otta Seal performance considering the severity of failure $\mathrm{P}_{1}$, the number of roads with the same degree of fatting-up, bleeding, and tracking was calculated in each period (Figure 13). After the beginning of exploitation on the 8 roads of $14 \mathrm{P}_{1}$ was less than $5 \%$ and on road number 2427 it was up to $50 \%$. The situation became worse and worse after each summer. In autumn 2015 on three roads sections (road number 4516 (1), road number 2427 , and road number 3918$) \mathrm{P}_{1}$ was up to $50 \%$ and on road number 1235 it was higher than $50 \%$. In hot summer days the pavement surface on these roads becomes sticky and hardly passable on foot. It results in inhabitants' complaints. The bitumen bleeds up because of inadequate binder content and uneven binder distribution within the nozzle beam. Some bleeding in specified areas and in the wheel paths is a normal part of the curing process for double Otta Seal. Typically, the fine aggregate has to be used for blinding-off. However, if bleeding is extensive, a coarse aggregate is more suitable. The spread aggregate has to be rolled. All works related to bleeding-off have to be conducted in the hot time of the day. On experimental roads these works had not been carried out.

The degree of pavement suffering from $\mathrm{P}_{2}$ (scabbing, tearing, and longitudinal joint crack) on each road section is shown in Figure 14. The most distressed roads sections are road number 1708 and road number 2735 . There the average amount of $\mathrm{P}_{2}$ within three years of operation is $4.14 \%$ and $3.19 \%$, respectively. The maximum value of $20.64 \%$ was determined in autumn 2012 on the road number 1708 . On 5 roads (road number 4516 (2), road number 3208, road number 4118 , road number 2427 , and road number 
TABLE 4: $\mathrm{P}_{1}$ (fatting-up, bleeding, and tracking) on roads section covered with double Otta Seal.

\begin{tabular}{|c|c|c|c|c|c|c|c|c|}
\hline \multirow{3}{*}{ Region } & \multirow{3}{*}{ Road number } & \multicolumn{7}{|c|}{$\mathrm{P}_{1}$ (fatting-up, bleeding, and tracking) (\%) } \\
\hline & & \multirow{2}{*}{$\begin{array}{c}2012 \\
\text { Autumn }\end{array}$} & \multicolumn{2}{|c|}{2013} & \multicolumn{2}{|c|}{2014} & \multicolumn{2}{|c|}{2015} \\
\hline & & & Spring & Autumn & Spring & Autumn & Spring & Autumn \\
\hline \multirow{4}{*}{ Klaipèda-Tauragè } & 1708 & 5 & 5 & 5 & 5 & 5 & 5 & 5 \\
\hline & 1717 & 30 & 30 & 30 & 30 & 30 & 30 & 30 \\
\hline & $4516(1)$ & 10 & 10 & 30 & 30 & 30 & 30 & 50 \\
\hline & $4516(2)$ & 5 & 5 & 10 & 10 & 5 & 5 & 10 \\
\hline \multirow{3}{*}{ Šiauliai-Telšiai } & 2735 & 5 & 5 & 5 & 5 & 5 & 5 & 5 \\
\hline & 3208 & 30 & 30 & 30 & 30 & 30 & 30 & 30 \\
\hline & 4118 & 5 & 5 & 10 & 10 & 10 & 5 & 10 \\
\hline \multirow{2}{*}{ Panevèžys-Utena } & 2427 & 50 & 50 & 50 & 30 & 50 & 30 & 50 \\
\hline & 1235 & 30 & 30 & 50 & 50 & $>50$ & 50 & $>50$ \\
\hline \multirow{3}{*}{ Vilnius-Alytus } & 3918 & 5 & 5 & 10 & 10 & 30 & 50 & 50 \\
\hline & 4726 & 5 & 5 & 5 & 5 & 5 & 5 & 5 \\
\hline & 5017 & 10 & 10 & 30 & 30 & 30 & 10 & 10 \\
\hline \multirow{2}{*}{ Kaunas-Marijampolè } & 5123 & 5 & 5 & 5 & 5 & 5 & 5 & 5 \\
\hline & 2642 & 5 & 5 & 5 & 5 & 5 & 5 & 5 \\
\hline
\end{tabular}

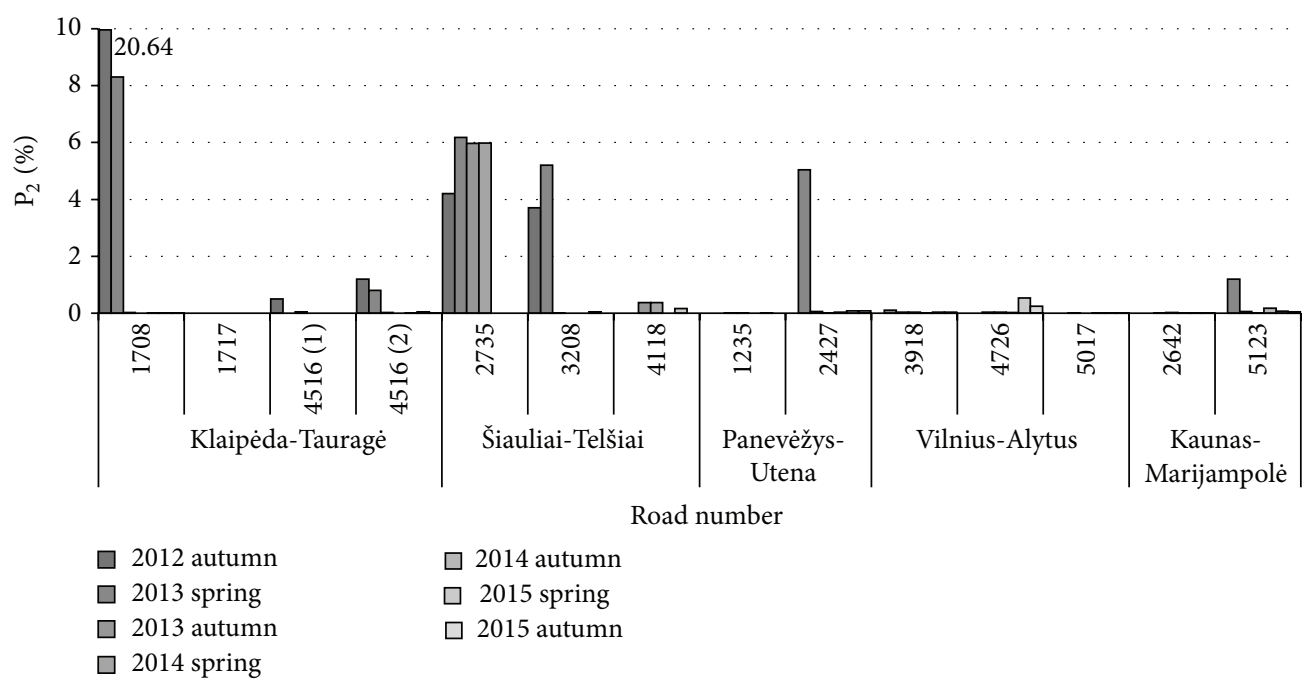

FIGURE 14: $\mathrm{P}_{2}$ (scabbing, tearing, and longitudinal joint crack) on roads sections covered with double Otta Seal.

4726) $\mathrm{P}_{2}$ varied from $0.1 \%$ to $1.3 \% .50 \%$ of roads (road number 1717, road number 4516 (1), road number 1235, road number 3918, road number 5017, road number 2642 , and road number 5123) are not prone to scabbing, tearing, and longitudinal joint cracking. On some roads (e.g., on road number 1708 , road number 2427) $\mathrm{P}_{2}$ decreased due to sealing of scabbing within routine maintenance. Scabbing occurred because of inadequate bond between the base and double Otta Seal. Light watering before spraying the binder enhances it. However, on all experimental roads, it was not done.

The degree of pavement suffering from $\mathrm{P}_{3}$ (streaking) on each road section is shown in Figure 15. The streaking was found only on 5 roads of the 14 in one year (from autumn 2013 to autumn 2014). The amount of $\mathrm{P}_{3}$ on each road varied from $5 \mathrm{~m}$ to $156 \mathrm{~m}$. The main cause of streaking is a lack of binder because of irregular transverse distribution of binder within the nozzle beam. Besides, a minimum period of $8-12$ weeks is needed between the construction of the first and the second layers. However, in all experimental roads, double Otta Seal was constructed at one stage. $\mathrm{P}_{3}$ might have disappeared because vehicles had pushed the aggregate particles deeper into binder.

\section{Conclusions}

The implemented research on soft asphalt and double Otta Seal performance within first three years revealed the following:

(i) The construction of soft asphalt and double Otta Seal is a reasonable solution for dustiness control on gravel 


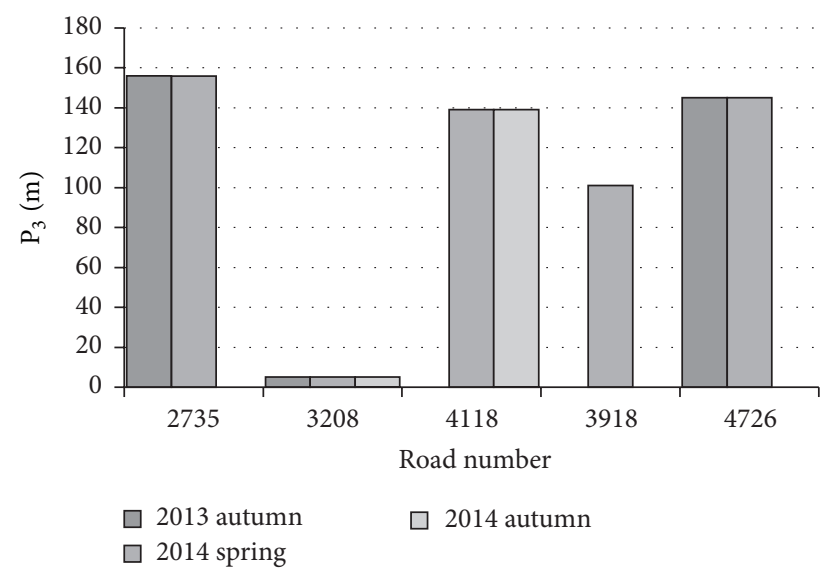

FIGURE 15: $\mathrm{P}_{3}$ (streaking) on roads sections covered with double Otta Seal.

roads with AADT and ESALs less than $500 \mathrm{vpd}$ and $0.1 \mathrm{mln}$, respectively.

(ii) As the bearing capacity of constructed roads base met technical regulation requirements it had no negative impact on soft asphalt and double Otta Seal performance. However, the deformation module $E_{v 2}$ of $120 \mathrm{MPa}$ has to be ensured not even at construction but also during exploitation phases.

(iii) All tested road sections met IRI requirement for roads of regional significance $(\leq 3.5 \mathrm{~m} / \mathrm{km})$. It can be stated that both technologies have no negative impact on pavement roughness after three years of exploitation.

(iv) Both technologies showed self-healing effect after warm seasons. Dependently on the road peculiarities and technology it was observed that from 13\% to $100 \%$ distresses healed after each summer.

(v) Longitudinal cracks, transverse cracks, and bleeding can be defined as dominant distresses of road sections with soft asphalt.

(vi) Fatting-up, bleeding, and tracking $\left(\mathrm{P}_{1}\right)$ and, on some roads, scabbing, tearing, and longitudinal joint crack $\left(\mathrm{P}_{2}\right)$ can be defined as dominant distresses of road sections covered with double Otta Seal.

(vii) There is not any evidential relationship between the degree of distresses and AADT, ESALs, or road section location.

(viii) Critical factor for road sections covered with double Otta Seal is incomplete construction and maintenance of constructed road sections. During construction phase light moistening should be applied on the base before bitumen emulsion spreading. Two-stage construction of first and second layer of double Otta Seal is strictly recommended; the second one should be applied not less than after four weeks of road exploitation and maintenance of emerged defects in first layer.

(ix) The trial emulsion and aggregate spreading and compaction rolling are strictly recommended for Otta
Seal technology in order to verify the emulsion and aggregate application rates and a sufficient number of roller passes.

\section{Competing Interests}

The authors declare that they have no competing interests.

\section{References}

[1] F. Praticò, S. Saride, and A. Puppala, "Comprehensive life-cycle cost analysis for selection of stabilization alternatives for better performance of low-volume roads," Transportation Research Record, no. 2204, pp. 120-129, 2011.

[2] A. Laurinavičius and D. Žilionienè, "Lithuanian state road network and its modernization," Transportas, vol. 16, no. 6, pp. 208-214, 2001.

[3] T. E. Jones, Dust Emission from Unpaved Roads in Kenya, Laboratory Report no. 1110, 1984.

[4] K. Edvardsson, "Gravel roads and dust suppression," Road Materials and Pavement Design, vol. 10, no. 3, pp. 439-469, 2009.

[5] S. Monlux and M. Mitchell, "Chloride stabilization of unpaved road aggregate surfacing," Transportation Research Record: Journal of the Transportation Research Board, vol. 1989, pp. 50-58, 2007.

[6] K. Gottschalk, Road Dust: A Survey of Particle Size, Elemental Composition, Human Respiratory Deposition and Clearance Mechanisms, Independent Study, Colorado State University, Ft Collins, Colo, USA, 1994.

[7] K. Donaldson, M. I. Gilmour, and W. MacNee, "Asthma and PM10," Respiratory Research, vol. 1, no. 1, pp. 12-15, 2000.

[8] B. Golden, "Impact of magnesium chloride dust control product on the environment," in Proceedings of the Transportation Association of Canada Annual Conference, vol. 1, pp. 1-6, Winnipeg, Canada, September 1991.

[9] J. M. Hoover, "Surface improvement and dust palliation of unpaved secondary roads and streets," Report ISU-ERI-AMES72316, 1973.

[10] T. G. Sanders, J. Q. Addo, A. Ariniello, and W. F. Heiden, "Relative effectiveness of road dust suppressants," Journal of Transportation Engineering, vol. 123, no. 5, pp. 393-397, 1997.

[11] E. Johnson and R. Olson, "Best practices for dust control on aggregate roads," Tech. Rep. MN/RC 2009-04, 2009.

[12] V. Vorobjovas, "Assurance of the function of low-volume roads for the improvement of driving conditions," The Baltic Journal of Road and Bridge Engineering, vol. 6, no. 1, pp. 67-75, 2011.

[13] V. Vorobjovas, T. Andriejauskas, and Z. Perveneckas, "Selection of soft asphalt pavements for low-volume roads in lithuania," in Proceedings of the 9th International Conference "Environmental Engineering 2014”, Vilnius, Lithuania, May 2014.

[14] V. Gintalas, "Longitudinal profile of the objects included in the gravel roads paving programme of Lithuania," Baltic Journal of Road and Bridge Engineering, vol. 2, no. 2, pp. 53-59, 2007.

[15] Finnish Pavement Technology Advisory Council PANK, Finnish Asphalt Specifications, PANK, 1995.

[16] Swedish National Road Administration, General Technical Construction Specifications for Roads, Chapter 1, Common Prerequisites; Chapter 3, Pavement Design; Chapter 6, Bitumen-Bound Layers, SNRA, 1996. 
[17] Roads and Traffic Research Society and Asphalt Roads Working Group, "Traffic Research Society and Asphalt Roads Working Group, Supplementary Technical Contract Specifications and Guidelines for the Construction of Carriageway Surfacing from Asphalt ZTV Asphalt-StB," 2000.

[18] M. I. Pinard and P. A. K. Greening, "Sustainable provision of low-volume sealed roads," in Proceedings of the 8th Conference on Asphalt Pavements for Southern Africa (CAPSA '04), pp. 1-15, September 2004.

[19] S. G. Joshi, M. Glory, M. Bhavan, and A. K. Jha, "Otta seal experience in Nepal," in Transportation Research Board, pp.1-11, 2013.

[20] C. Overby, A Guide to the Use of Otta Seals, Norwegian Public Roads Administration, Oslo, Norway, 1999.

[21] C. Overby and M. Pinard, "Otta seal surfacing: practical and economic alternative to traditional bituminous surface treatments," Transportation Research Record, vol. 2349, pp. 136-144, 2013.

[22] C. Overby, "Otta surfacing-a durable and cost effective global solution for low volume sealed roads," in Proceedings of the 9th Road Engineering Association of Asia and Australiasian Conference (REAAA '98), pp. 348-355, Wellington, New Zealand, 1998.

[23] Z. Perveneckas, A. Vaitkus, and V. Vorobjovas, "Soft asphalt pavements-solution for low traffic volume roads in Lithuania," in Proceedings of the in 28th International Baltic Road Conference, pp. 1-11, Vilnius , Lithuania, August 2013.

[24] A. Vaitkus, V. Vorobjovas, D. Čygas, and A. Pakalnis, "Soft asphalt pavement-solution for low-volume roads in changing climate and economy," Advanced Materials Research, vol. 934, pp. 47-52, 2014. 

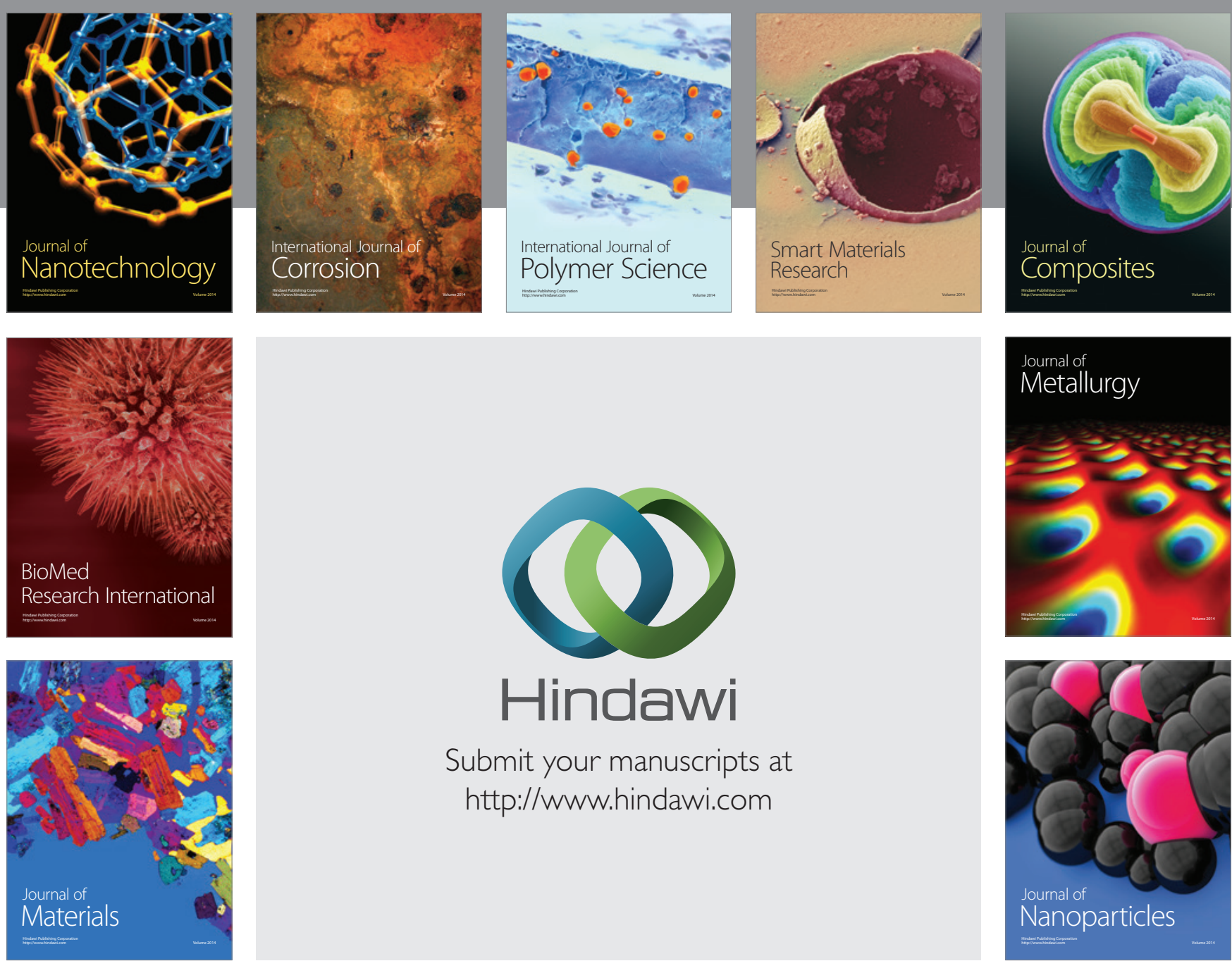

\section{Hindawi}

Submit your manuscripts at

http://www.hindawi.com

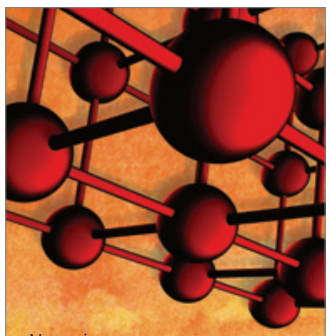

Materials Science and Engineering
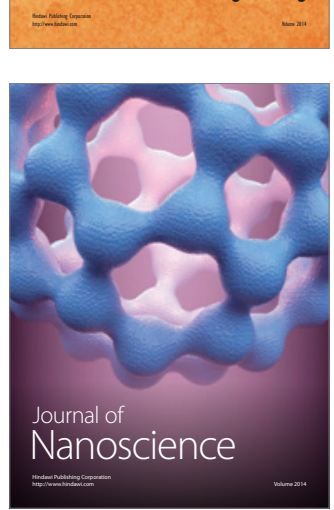
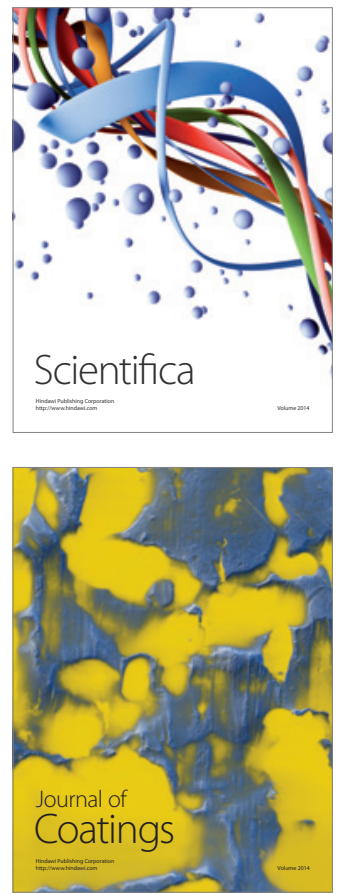
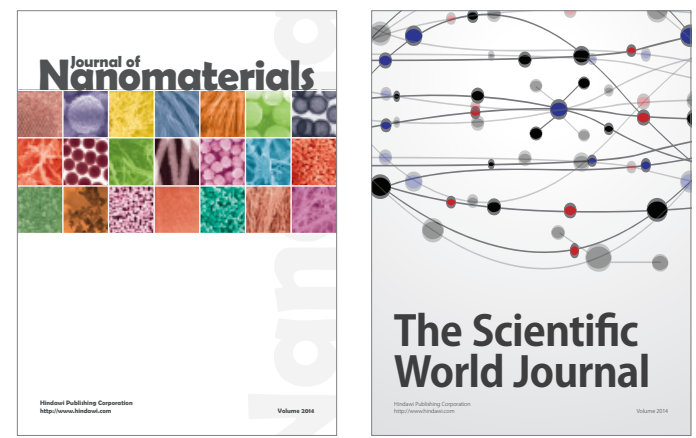

The Scientific World Journal
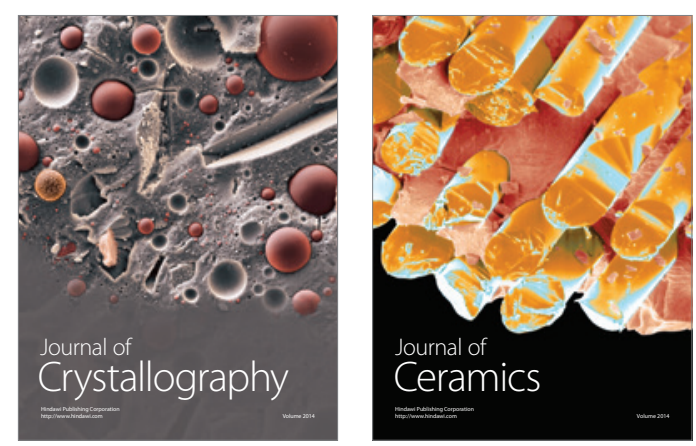
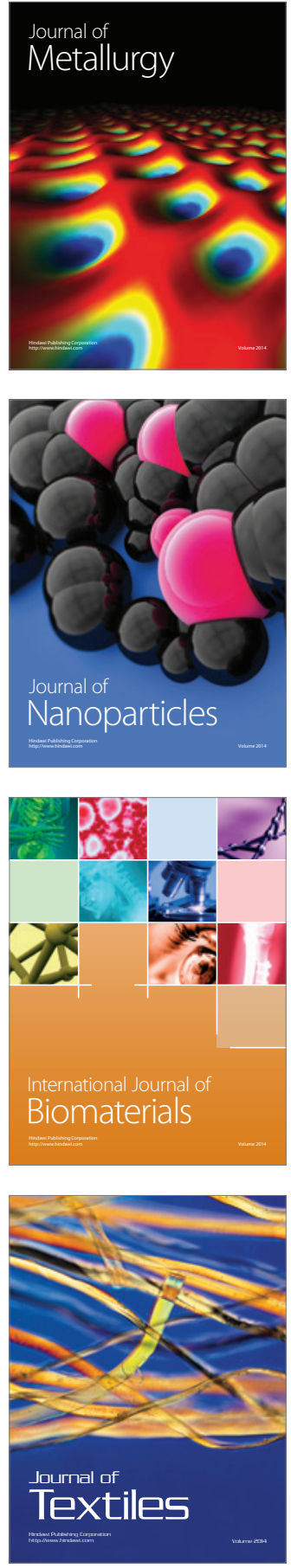